Politica, Vol. 7, No. 2, Juli-Desember 2020

PENERAPAN SYARIAT ISLAM DI PERBATASAN ACEH SUMATERA UTARA (Straegi Dinas Syariat Islam Aceh Tamiang)

\author{
Oleh \\ Mursyidin AR \\ Dosen Fakutas Syariah IAIN Langsa
}

\begin{abstract}
ABSTRAKSI
Implementasi Syariat Islam di Kabupaten Aceh Tamiang memiliki strategi yang ditempuh oleh Dinas Syariat Islam. Berbagai tantangan yang dihadapi, mapa upaya yang ditempuh oleh dinas Syariat Islam untuk keberhasilan Implementasi Syari'at Islam kepada masyarakat menggunakan strategi pembinaan dengan mengirim kaderkader ulama dalam memberikan penyuluhan kepada masyarakat dan membentuk lembaga pendidikan seperti TPA, dayah/pesantren.

Hasil pengamatan dapat dilihat bahwa strategi yang ditempuh adalah impelentasi tentang akidah serta melakukan pencegahan dan pengawasan terhadapp pendangkalannya, sementara dibidang ibadah, belum menunjukan peningkatan, dibidang syi'ar Islam sedikit medapatkan peningkatan, segingga Dinas Syariat Islam dalam penerapan Syariat Islam di Kabupaten Aceh Tamiang masih kuwalahan menghadapinya, disebabkan masih kurang memadai dan belum mendapatkan respon dari masyarakat secara merata. masyarakat yang melaksanakan Syari'at Islam itu sesuai dengan qanun Syari'at Islam. Dengan demikian, hambatan dan upaya Dinas Syariat Islam dalam mengatasi implementasi Syariat Islam di Kabupaten Aceh Tamiang kurangnya Sumber Daya Manusia yang profesional dalam melaksanakan tugasnya, kondisi georgarfis yang jauh dari pusat pengawasan DSI dan WH, sehingga pelanggaran Syari'at Islam di daerah ini masih tinggi. Maka, upaya yang dilakukan Dinas Syari'at Islam mengandalkan potensi dan sumber daya yang ada dan berkomitmen mengimplementasikan syari'at Islam kepada masyarakat Aceh Tamiang.
\end{abstract}

Kata Kunci : Strategi, Implementasi dan Syari’at Islam. 
Politica, Vol. 7, No. 2, Juli-Desember 2020

\section{A. LATAR BELAKANG MASALAH}

Perkembangan syariat Islam di Indonesia ditandai dengan adanya menguatnya otonomi daerah untuk mengatur sistem kepemerintahan sendiri. ${ }^{1}$ Hak istimewa yang diberikan oleh pemerintah pusat kepada Provinsi Aceh adalah merupakan kesempatan penerapan syariat Islam. Era reformasi ternyata telah berhasil menempuh hak otonomi bagi daerah-daerah di seluruh Indonesia, bahkan otonomi kepada Provinsi Aceh untuk dapat melaksanakan Syariat Islam. Maka dengan lahirnya Undang-undang Nomor 44 Tahun 1999 tentang Penyelenggaraan Keistimewaan Propinsi Daerah Istimewa Aceh (Lembaran Negara Republik Indonesia Tahun 1999 Nomor 172, Tambahan Lembaran Negara Nomor 3839), Kemudian lebih dipertegas lagi dengan lahirnya Undang-undang Nomor 18 Tahun 2001 tentang Otonomi Khusus bagi Propinsi Daerah Istimewa Aceh sebagai Propinsi Nanggroe Aceh Darussalam (NAD) (Lembaran Negara Republik Indonesia Tahun 2001 Nomor 114, Tambahan Lembaran Negara Nomor 4134). Terakhirlebih dioperasionalkan lagi oleh Keputusan Presiden Republik Indonesia (Keppres) Nomor: 11 Tahun 2003 tanggal 3 Maret 2003 tentang Mahkamah Syariah dan Mahkamah Syariah Propinsi di Propinsi Nanggroe Aceh Darussalam.

Penerapan Syariat Islam di Aceh sepanjang diberlakukannya sampai saat sekarang yang sangat populer hanya sebatas pada penerapan Qanun Nomor 11 Tahun 2002 tentang Pelaksanaan Syariat Islam bidang Aqidah, Ibadah dan Syiar Islam, yang di dalamnya memuat tentang aliran sesat, Shalat jumat, puasa di bulan Ramadhan dan berbusana Islami, Qanun Nomor 12 Tahun 2003 tentang Khamar, Qanun Nomor 13 tentang Maisir (perjudian) dan Qanun Nomor: 14 Tahun 2003 tentang Khalwat (Mesum). Landasan ini kemudian diperkuat oleh UndangUndang Republik Indonesia Nomor: 11 Tahun 2006 tentang Pemerintahan Aceh yang semakin mengukuhkan untuk pemberlakuan atau penerapan Syariat Islam di Aceh secara koprehensif. Demikian juga, sebagai penyambung kekuasaan kepada pemerintah kabupaten/Kota dalam wilayah Provinsi Aceh termasuk di Kabupaten Aceh Tamiang. Untuk menunjang dan mendukung agar penerapan Syariat Islam berjalan dengan cepat dan lancar ke tengah-tengah masyarakat, maka Dinas Syariat Islam Kabupaten Aceh Tamiang memiliki peranan yang cukup luas untuk mengimplementasikan segala yang berkaitan dengan pemberlakuan Syariat Islam.

Kabupaten Aceh Tamiang adalah salah satu Kabupaten di Provinsi Aceh yang berbatasan langsung dengan Provinsi Sumatera Utara dan merupakan pintu gerbang masuknya warga dari berbagai Provinsi yang ada di Indonesia menuju Aceh melalui jalur lintas Timur. Keberagaman penduduknyapun, mulai dari suku,

\footnotetext{
${ }^{1}$ Terkandung esensinya dalam Pasal 18 UUD 1945 bahwa keberadaan daerah otonom dalam penyelenggaraan Pemerintah Daerah yang didasarkan pada azas desentralisasi. Lihat Juga: Ni matul Huda, Otonomi Daerah: Filosofi, Sejarah perkembangan dan Problematika, (Yokyakarta: Pustaka Pelajar, 2009), Cer II, hlm. 3
} 
budaya dan adat istiadat, mata pencaharian dan agama membuat keberagamaan cara pandang masyarakat terhadap penerapan Syariat Islam dan hal ini sangat wajar terjadi mengingat beground warga masyarakat yang berbeda-beda. Maka, penelitian ini menjadi urgen untuk dikaji dari sudut pola komunikasi, yakni pola komunikasi yang dilakukan oleh Dinas Syariat Islam Kabupaten Aceh Tamiang dalam memberikan pemahaman kepada masyarakat mengenai implementasi Syariat Islam. Tanpa mengesampingkan berbagai upaya yang sudah dilaksanakan sebelumnya dan menepis anggapan bahwa Dinas Syariat Islam sama sekali belum berperan dan belum menunjukkan fungsi serta tanggung jawabnya sebagai salah satu lembaga yang diamanatkan Pemerintah Aceh dalam penerapan Syariat Islam.

Kontradiksi dalam memahami implementasi Syariat Islam di Kabupaten Aceh Tamiang sangat kental terjadi di tengah-tengah masyarakat, hal ini ditandai dengan masih maraknya sebahagian dari warga masyarakat yang melanggar aturan dari pemberlakuan Syariat Islam, seperti: melakukan perjudian, mabukmabukan dengan minuman keras, berkhalwat dan menjamurnya busana yang tidak Islami khususnya lagi bagi kaum perempuan.

Penerapan syariat Islam di Aceh Tamiang berbeda dengan kabupaten/kota yang di di Aceh, seperti Kota Langsa, Kota Lhok seumawe, Kabupaten Bireun, dan Kabupaten Aceh Barat. Di mana daerah tersebut lebih populer dalam penerapan Syari'at Islam. sementara Kabupaten Aceh Tamiang perjalanan penerapan Syari'at Islamnya terkesan lamban sehingga kurang terpublikasi ke tengah-tengah masyarakat.

Dengan demikian, perlu dikaji lebih mendalam dan tajam menegenai pola dan strategi penerapan syariat Islam di Aceh Tamiang untuk melahirkan konsep bagi pejabat pengambil/penentu kebijakan, sehingga dapat dijelaskan secara dekriptif teoritis undapat melahirkan sebuah analisis realitis.

\section{B. TEORI PENERAPAN SAYARIAT ISLAM}

Aceh adalah sebuah Provinsi yang terletak di ujung sebelah utara pulau Sumatera yaitu Provinsi Aceh. Provinsi Aceh ini yang sebelumnya diberi gelar dengan Daerah Istimewa Aceh, kemudian dirubah dengan nama Nanggroe Aceh Darussalam. ${ }^{2}$ Aceh sekarang telah memberlakukan syariat Islam secara Kaffah, namun pelaksanaannya belum memenuhi kehendah yang telah diterapkan dalam Alquran dan Hadis, masih banyak pelanggaran-pelanggaran di derah ini yang

\footnotetext{
${ }^{2}$ Pemberian nama Daerah Istimewa Aceh berdasarkan UU No. 24 tahun 1956 Pembentukan Daerah Otonom Propinsi Atjeh. Diberlakukan hak Istimewa berdasarkan UUNRI No. 44 tahun 1999 tentang Pemberlakukan Hak Insimewa Aceh. Selanjutnya, Pemberian nama Nanggroe Aceh Darussalam (NAD) pada Tahun 2001-2009 berdasarkan UU Nomor 18 Tahun 2001 tentang Otonomi khusus Bagi Provinsi Daerah Istimewa Aceh sebagai Provinsi NanggroeAceh Darussalam, yang disahkan pada tanggal 19 Juli 2001 dan diundangkanpada tanggal 9 Agustus 2001.
} 
belum sepenuhnya dapat diatasi. Aceh yang merupakan daerah modal dalam memperjuangkan kemerdekaan Indonesea, kini telah melakukan formalisasi syariat Islam telah berjalan beberapa tahun yang lalu agar dapat berjalan penerapan syariat Islam dengan baik dalam bebarbagai aspek.

Teory yang akan dikaji adalah secara normatif dalam berbagai leteratur. Hal ini melihat sumber hukum Islam baik dari Alquran, Sunnah secara umum. ${ }^{3}$ Berideologi Islam, mencoba untuk menumbuhkan diskursus tentang penerapan syari'at Islam di Kab. Aceh Tamiang, yaitu dengan menggunakan Alqur'an dan Hadis sebagai dasar Hukum. ${ }^{4}$ Alquran memerintahkan untuk berpegang kepada hukum Allah swt. ${ }^{5}$ Hal ini dilakukan untuk menarik dukungan pemerintah dan masyarakat Aceh secara umum, terutama yang memandang bahwa segala sistem pemerintahan harus diberlakukan dengan menggunakan sistem Syariat Islam. Memberlakukan hukum Islam di atas bumi ini sebagai hukum wajib yang harus diupayakan sebagai kebijakan dan tindakan yang diambil pada manusia.

Disamping teori yang diambil dari Alquran, teori lain sebagai teori dasar, maka dapat dilihat teori-teori lain dari berbagai sumber. Teori yang mengggunakan teori Struktural Funsional dan August Comte merupakan pencetus teori yang disebut struktur-fungsi, struktural fungsional, fungsionalime, ataupun fungsionalisme struktural itu ${ }^{6}$ dengan pendekatan sosiologi yang diterapkan di institusi/lembaga pemerintah. Dalam hal ini yang dimaksudkan pemerintah adalah Pemerintahan Kabupaten Aceh Tamiang dengan lembaganya ialah Dinas Syari'at Islam.

Pendekatan ini mempunyai warna yang jelas, yaitu mengakui adanya segala keragaman dalam kehidupan sosial dan masyarakat Aceh Tamiang adalah masyarakat yang beragam, baik dari suku, budaya dan agama. Keragaman ini merupakan sumber utama dari adanya struktur masyarakat serta akhirnya

\footnotetext{
${ }^{3}$ Kesempurnaan syariat Islam juga didasarkan pada Alquran Surat al Maidah: 3, al Nahl: 89, "Dan Kami turunkan kepadamu al-Kitab (Alquran) untuk menjelaskan segala sesuatu." Menurut Mahmud Syaltut, bahwa Alquran memperkenalkan dirinya sebagai "tibyanan likulli syay'in", yaitu dalam Alquran terdapat segala unsur petunjuk menyangkut berbahagia problematika kihidupan duniawi dan ukhrawi. Jadi, kiranya cukup berdasar kalau ayat tersebut dijadikan sebagai bukti bahwa syariat Islam harus dilakukan sosialisasi kepada seluruh elemen masyarakat. Hal ini dilanjutkan dalam al-An'am: 38 disebutkan, "Tiadalah Kami alpakan sesuatu pun di dalam alKitab." Yaitu bahwa Alquran tidak meninggalkan sedikitpun dan atau lengah dalam memberikan keterangan mengenai segala sesuatu yang berhubungan dengan tujuan-tujuan pokok Alquran, yaitu masalah-masalah akidah, syariah, dan akhlak, bukan sebagai apa yang dimengerti oleh sebagian ulama bahwa ia mencakup segala macam ilmu pengetahuan saja.

${ }^{4}$ Surah Al-Baqarah, 2:229, 2:178, 2:179, Al-Ma'idah: 45, Al-Ma'idah: 38, 33, An- Nur: 2, 4,An-Nisaa' Ayat 15, Al- Maidah: 90, An-Nisa'a: 92, 93.

${ }^{5}$ Dalam Alquran disebutkan Artinya: "Allah tidak menurunkan suatu keteranganpun tentang nama-nama itu. Keputusan itu hanyalah kepunyaan Allah. dia Telah memerintahkan agar kamu tidak menyembah selain Dia. Itulah agama yang lurus," (QS. Yusuf/12:40).

${ }^{6}$ Sunarto, Kamanto, Pengantar Sosiologi, (Jakarta : Lembaga Penerbit FE UI, 2004), hal. 228
} 
keragaman dalam fungsi sesuai dengan posisi seseorang dalam struktur sebuah sistem. Seperti dalam sebuah organisasi sosial pasti memiliki posisi masingmasing sebagai jabatan ketua, sekretaris atau anggota biasa. Tentunya kedudukan seseorang dalam struktur organisasi akan menentukan fungsinya, yang masingmasing berbeda. Namun perbedaan fungsi ini tidak untuk memenuhi kepentingan individu yang bersangkutan, tetapi untuk mencapai tujuan organisasi sebagai kesatuan. Tentunya, struktur dan fungsi ini tidak akan pemah lepas dari pengaruh budaya, norma, dan nilai-nilai yang melandasi sistem masyarakat itu. ${ }^{7}$

Struktur organisasi yang dapat disebut adalah struktur organisasi dalam jajaran Dinas Syari'at Islam yang memiliki jabatan berjenjang di dalamnya dengan satu tujuan yakni menjalankan visi dan misi yang telah ditetapkan.

Di samping itu juga, teori ini memandang bahwa masyarakat merupakan satu kesatuan yang utuh dengan memiliki tiga asumsi dasar yang dimiliki, yakni evolusi, harmoni dan stabilitas. Namun yang paling utama adalah stabilitas karena masyarakat tidak akan bertahan dialam semesta ini kalau tidak ada stabilitas. Sedangkan evolusi adalah bahwa perubahan yang terjadi didalam masyarakat itu prosesnya secara perlahan melalui adaptasi-adaptasi tertentu.

Merton membedakan perubahan yang terjadi pada masyarakat menjadi dua, yakni; fungsi dan disfungsi serta yang dimaksud dengan fungsi apabila perubahan yang terjadi itu mengarah pada ranah positif yang menuntun pada arah stabilitas. Maka ketika fungsi tersebut disadari dan memang diniati untuk dilakukan oleh sebuah masyarakat dan latent function, saat fungsi tersebut tidak disadari dan tidak diniatkan oleh sebuah masyarakat. Disebut disfungsi apabila perubahan yang terjadi di masyarakat itu mengarah kejalan reduksi terhadap stabilitas. ${ }^{8}$

Perubahan-perubahan tersebut terjadi setelah ada tekanan-tekanan kemudian terjadi integrasi dan berakhir pada titik keseimbangan (homeostatic) meskipun tidak bisa sempurna, Artinya teori ini melihat adanya ketidak seimbangan yang abadi yang akan berlangsung seperti sebuah siklus untuk mewujudkan keseimbangan baru, setiap sistem selalu mengalami ketegangan dan penyimpangan namun bisa dinetralisir melalui institusionalisasi. ${ }^{9}$ Variabel yang menjadi perhatian teori ini adalah struktur sosial serta berbagai dinamikanya. Penyebab perubahan dapat berasal dari dalam maupun dari luar sistem sosial.

Bentuk atau sistem, cara atau bentuk (struktur) yang tetap, yang mana pola dapat dikatakan contoh atau cetakan atau disebut juga dengan model, yaitu cara untuk menunjukkan sebuah objek yang mengandung kompleksitas proses

\footnotetext{
${ }^{7}$ R. Megawangi,R, Membiarkan Berbeda : Sudut Pandang Baru Tentang Relasi Gender, (Jakarta: Pustaka Mizan, 2001), hlm. 19

${ }^{8}$ Puspitawati, Herien. 2009. Teori Struktural Fungsional dan Aplikasinya Dalam Kehidupan Keluarga, (Bogor : Departemen Ilmu Keluarga dan Konsumen, 2009), hlm. 2.

${ }_{9}$ Robert H. Lauer, Perspektif Tentang Perubahan Sosial, alih bahasa Alimandan. (Jakarta : Bina Aksara, 1989), hlm. 105-106
} 
didalamnya dan hubungan antara unsur-unsur pendukungnya. ${ }^{10}$ Menurut Little Jhon model dapat diterapkan pada setiap representasi simbolik dari suatu benda. ${ }^{11}$

Maka dengan demikian strategi penerapan syariat Islam di Perbatasan Aceh Tamiang itu perlu di perhatikan dan diciptakann kebijakan-kebijakan dari pemerintah Aceh Tamiang sampai terserapp keseluruh lapisan masyarakat.

Ada tiga faktor pembentukan strategi penerapan, yaitu (1) proses sejarah atau pengalaman masa lalu yang kemudian membentuk kebiasaan-kebiasaan yang menjadi bagian dari kepribadian, (2) kapasitas diri sebagai akibat dari faktor pendidikan, pelatihan serta pengalaman hidup diri seseorang dalam menempuh kehidupan, dan (3) maksud dan tujuan dari aktivitas serta strategi penerapan syariat Islam membawa kepada perubahan yangg sesuai dengan perubahan sosial.

Dengan demikian, maka Dinas Syari'at Islam sebagai sebuah instansi inti yang sangat menentukan dalam pelaksanaan Syari'at Islam khususnya di Aceh Tamiang dalam konteks Undang-undang nomor 44 Tahun 1999 dan Undangundang Nomor 18 Tahun 2001. Dinas Syari'at Islam merupakan instansi paling depan dalam rangka impemantasi dan pelaksanaan Syari'at Islam di NAD di dukung oleh semua Dinas Syari'at Islam tingkat Kabupaten/Kota dalam upaya pelaksanaan Syari'at Islam tersebut. Dasar hukum pembentukan Dinas Syari'at Islam adalah dengan keluarnya Perda Nomor 5 Tahun 2001. ${ }^{12}$

\section{STRATEGI PENERAPAN SYARIAT ISLAM DI ACEH TAMING}

\section{Dinas Syariat Islam Kabupaten Aceh Tamiang}

Kabupaten Aceh Tamiang ini merupakan hasil pemekaran dari Kabupaten Aceh Timur terletak di perbatasan Aceh-Sumatera Utara yang berdiri pada tahun 2002 dengan luas wilayah 1.957,02 $\mathrm{Km}^{2}$ terdiri dari 12 Kecamatan. ${ }^{13}$ Kabupaten Aceh Tamiang merupakan pintu gerbang masuknya warga di luar Provinsi Aceh, maka percaturan dan pertukaran budaya sangat cepat terjadi, termasuk di dalamnya penerapan Syariat Islam yang dapat dikatakan masih belum maksimal.

Dinas Syari'at Islam Nanggroe Aceh Darussalam (NAD) merupakan sebuah instansi inti yang sangat menentukan dalam pelaksanaan Syari'at Islam di Aceh dalam konteks Undang-undang nomor 44 Tahun 1999 dan Undang-undang Nomor 18 Tahun 2001. Dinas Syari'at Islam merupakan instansi paling depan dalam rangka impemantasi dan pelaksanaan Syari'at Islam di NAD di dukung oleh semua Dinas Syari'at Islam tingkat Kabupaten/Kota dalam upaya pelaksanaan Syari'at Islam tersebut. Dasar hukum pembentukan Dinas Syari'at

\footnotetext{
${ }^{10}$ Wiryanto, Pengantar Ilmu Komunikasi, (Jakarta: Gramedia Widiasavina:2004), hlm.9.

${ }^{11}$ Ibid.

${ }^{12}$ Hasanuddin Yusuf Adan, Repleksi Implementasi Syari'at Islam di Aceh, (Banda Aceh : Adnin Foundation Publisher \& Pena, 2009), hlm. 13-14.

${ }^{13}$ www.acehtamiangkab.go.id, di akses pada tanggal 20 Mei 2014
} 
Islam adalah dengan keluarnya Perda Nomor 5 Tahun 2001. ${ }^{14}$ Pembentukan Kantor Syari'at Islam sesuai dengan Keputusan Bupati Aceh Tamiang nomor 023 Tahun 2003 tanggal 01 September 2003 tentang Pembentukan, Susunan Organisasi dan Tata Kerja Kantor Syariat Islam Kabupaten Aceh Tamiang dan berubah status menjadi dinas sesuai dengan Qanun Kabupaten Aceh Tamiang nomor 3 Taun 2007 tanggal 20 Maret 2007 tentang Penataan Susunan Organisasi dan Tata Kerja Dinas-Dinas Daerah Kabupaten Aceh Tamiang.

Upaya legislasi pelaksanaan Syariat Islam sebagaimana di atur dalam qanun adalah upaya membina, menjaga, memelihara dan melindungi aqidah umat Islam di Nanggroe Aceh Darussalam dari berbagai paham atau aliran sesat, sedangkan ancaman hukuman bagi setiap orang yang melanggara secara sengaja keluar dari aqidah Islam dan atau menghina atau melecehkan agama Islam.

Demikian pula dengan peraturan aspek ibadah, baik shalat fardhu/jum'at maupun puasa ramadan dimaksudkan untuk mendorong, menggalakan orang Islam untuk melaksanakan dan meningkatkan kualitas iman dan kualitas amal, serta intensitas ibadah sebagai wujud pengabdiannya yang hanya diperuntuhkan kepada Allah swt semata. Upaya tersebut perlu juga didukung oleh kondisi dan situasi pelaksanaan Syi'ar Islam, namun masih dalam ruang lingkup nilai ibadah.

\section{Proses Implementasi Syariat Islam di Aceh Tamiang}

Penerapan Syari'at Islam yang diperankan oleh Dinas Syari'at Islam Kabupaten Aceh Tamiang adalah melalui berbagai cara, mulai dari program kerja Bidang yang terstuktur dalam jajaran kepegawaiannya, yaitu : Bidang Dakwah dan Peribadatan, Bidang Bina Sumber Daya Manusia, Bidang Penelitian dan Pengembangan serta Bidang Pengawasan sampai pada kerja sama dan koordinasi dengan lembaga/instansi terkait dalam dan luar daerah yang menunjang terlaksananya program pelaksanaan Syari'at Islam yang dijalankan.

Secara umum, pelaksnaan Syari'at Islam di Aceh Tamiang memiliki muatan yang sama di kabupaten lainnya dalam Provinsi Aceh. Namun di Aceh Tamiang tidaklah menunjukan hal yang signifikan, bahwa program kegiatan, struktur organisasi dan implementasinya bermuara pada situasi dan kondisi daerahnya saja. Mengenai landasan yuridisnya sudah barang tentu mengacu pada aturan yang berlaku dan ditetapkan di Aceh ini.

Fenomena yang berkembang tentang pelaksanaan Syari'at Islam di Aceh Tamiang secara kasat mata dapat dikatakan belum mencapai hal yang maksimal. Hal ini dapat dilihat dari tata cara berbusana para remaja putrinya. Lebih banyak dari kaum perempuan yang tidak berbusana Islami dari pada yang berbusana Islami, masih banyak yang berkeliaran dan beraktifitas (bekerja) pada saat azan

\footnotetext{
${ }^{14}$ Hasanuddin Yusuf Adan, Repleksi Implementasi Syari'at Islam di Aceh, (Banda Aceh : Adnin Foundation Publisher \& Pena, 2009), hlm. 13-14.
} 
berkumandang, sedikit sekali yang hadir pada saat acara pengajian atau ceramah keagamaan dilaksanakan, jika bulan Ramadhan saja masih ada yang berani merokok secara terang-terangan dan berjualan makanan di siang hari secara terbuka dan masih banyak lagi yang dapat disaksikan tentang pelaksanaan Syari'at Islam di Aceh Tamiang ini. Bahkan yang lebih ironisnya lagi, sebahagian pejabat Pemerintah Daerah tidak peduli sama sekali dengan pemberlakuan Syari'at Islam dan melakukan salah satu larangan dari Syari'at Islam itu sendiri.

Dengan demikian penerapan Syari'at Islam di Aceh Tamiang yang melakukan perubahan. Dinas Syari'at Islam Kabupaten Aceh Tamiang membuatan melalui sisran-siaran, pengajian, penyuluhan, dan ceramah secara berkelompok.

3. Pelaksanaan Syariat Islam Bidang Aqidah, Ibadah dan Syiar Islam Tatanan kebebasan dan ketertiban diatur oleh hukum (the rule of low) ${ }^{15}$ yang diterapkan penguasa kepada masyarakat berdasarkan koridor hukum. Maka pemerintah Kab. Aceh Tamiang menerapkan Qanun No. 11 Tahun 2002 Bidang Aqidah, Ibadah dan Syi'ar Islam di Aceh yang bermuara pada apa yang telah dituangkan dalam qanun itu sendiri, seperti :

\section{Bidang Aqidah}

Mengantisipasi alitran sesat, Dinas Syari'at Islam mengambil strategi untuk mendatangi langsung ke tengah-tengah masyarakat adalah melalui dengan personal approach (pendekatan individual) yang berada lokasi yang menjadi markas atau aktivitas jama'ah tersebut. Kemudian jika mengandung unsur-unsur yang menjurus kepada kesesatan diberikan peringatan terlebih dahulu melalui surat, jika tidak diindahkan oleh jama'ah tersebut, maka dilaporkan kepada Majelis Permusyawaratan Ulama (MPU) untuk di tindak lanjut tentang keberadaan dan kebenaran jama'ah tersebut. Unsur kerja sama ini tidak dapat ditinggalkan karena yang berhak menetapkan sebuah aliran itu sesat adalah dari pihak Majelis Permusyawaratan Ulama (MPU). Sementara Dinas Syari'at Islam hanya sebatas mempasilitasi jalannya proses eksekusi yang dilaksanakan oleh lembaga penegak hukum. Terkhusus bagi aliran atau ajara sesat, apakah masih layak untuk di perbolehkan keberadaannya ataupun tidak. Hal ini disesuikan dengan keputusannya MPU.

Mensikapi implemnetasi Qanun ini Dinas Syariat Islam perlu melakukan koordinasi dengan MPU dan dinas-dinas terkait lainnya dalam lingkungan kabupaten Aceh Tamiang sebagai strategis dalam menjembatani kedangkalan

\footnotetext{
${ }^{15}$ Ahmad Kamil dan M Fauzan, Kaedah-Kaedah Hukum Yurisprudensi, (Jakarta: Kencana, 2008), Ed.I, Cet. III, hlm.19
} 
aqidah masyarakat dan mencermati munculnya aliran atau ajaran sesat di aceh Tamiang, yaitu :

1. Bekerja sama dengan para ustaz/ustazah Taman Pendidikan Al-Qur'an (TPA) dalam wilayah Kabupaten Aceh Tamiang untuk membina anak-anak usia dini dari pengaruh budaya asing dan memberikan pengetahuan keislaman yang benar.

2. Berkoordinasi dengan Majelis Permusyawaratan Ulama (MPU) dalam rangka memberikan penyuluhan dan pembinaan ke tengah-tengah masyarakat, baik diminta ataupun tidak dengan metode ceramah dan diskusi tentang bahaya aliran sesat dan pentingnya hidup di bawah naungan Islam.

3. Membuka jaringan kerja sama dengan Organisasi Keislaman untuk saling berkomunikasi dan berkoordinasi apabila ada ajaran sesat yang muncul dengan memberikan penyadaran terlebih dahulu kepada orang atau kelompok jama'ah yang diduga telah menyimpang dari ajaran Islam.

4. Selalu menyempatkan diri untuk menyampaikan pesan dalam setiap kesempatan di acara-acara yang diadakan dan diikuti oleh personil Dinas Syari'at Islam.

5. Menggali dan mengkaji potensi yang dapat memunculkan ajaran atau aliran sesat serta selalu berkoordinasi dengan lembaga/instansi terkait dan yang berkompoten dalam menanggulanginya.

Antisipasi aliran sesat yang kemungkinan terjadi di Kabupaten Aceh Tamiang, jika benar-benar meresahkan masyarakat dan ada laporan dari masyarakat bahwa ada orang/sekelompok orang (jama'ah) yang sudah menyimpang dari ajaran Islam, maka sebagaimana biasanya Pol. WH akan turun langsung kelokasi kejadian dengan melakukan observasi pembenarannya atau berkoordinasi dengan tokoh masyarakat setempat dan secara cepat melakukan musyawarah dengan perangkat Kampung. Jika orang/sekelompok orang tersebut masih melakukan kegiatannya, maka akan dikoordinasikan dengan Majelis Permusyawaratan Ulama (MPU) untuk dikaji lebih lanjut agar segera diambil tindakan supaya tidak menimbulkan keresahan bahkan sikap anarkis di tengahtengah masyarakat.

2. Bidang Ibadah, Bidang Ibadah yang mencakup tentang Shalat Jum'at, Puasa pada Bulan Ramadhan dan Berbusana Islami.

Dinas Syari'at Islam melalui Kepala Bidang Dakwah dan Peribadatan menguraikan implementasi keberadaan qanun ini di Aceh Tamiang adalah dengan berbagai kegiatan dan sosialisasi ke tengah-tengah masyarakat, seperti :

a. Mengadakan pembekalan dan pelatihan bagi Imam dan Khatib dalam wilayah Aceh Tamiang; di sinilah Bidang Dakwah dan Peribadatan menyampaikan 
Politica, Vol. 7, No. 2, Juli-Desember 2020

tentang isi Pasal di atas yang terkandung dalam qanun tersebut sekaligus membagikan isi qanun tersebut secara tertulis.

b. Menjadi fasilitator pada pengajian rutin yang dilaksanakan setiap satu bulan sekali diikuti oleh seluruh instansi dalam jajaran Pemda Kabupaten Aceh Tamiang; walau hanya satu bulan sekali pelaksanaannya namun momentum ini dapat dimanfaatkan untuk mensosialisasikan tentang keberadaan Syari'at Islam yang tertuang di dalam qanun.

c. Mempasilitasi setiap acara keagamaan yang dilaksanakan oleh Pemda Aceh Tamiang; pada setiap Peringatan Hari-hari Besar Islam (PHBI) Dinas Islam selalu dipercayakan untuk mempasilitasi acaranya atau sebagai panitia penyelenggara, seperti Musabaqah TilawatilQur'an (MTQ).

Dinas Syari'at Islam Kabupaten Aceh Tamiang yang telah dianggap sebagai lembaga yang berkompoten dan harus bertanggung jawab dalam mengurusi tentang pelaksanaan Syari'at Islam, maka dengan adanya penempatan tenaga da'i dari Provinsi Aceh yang ditempatkan di Kabupaten Aceh Tamiang dapat menjadi mata rantai dan mitra kerja dalam pembinaan ibadah di tengah-tengah masyarakat. Da'i perbatasan demikian populernya, Tugas dan peran yang dijalan oleh para da'i tersebut sangat membantu program Kedinasaan.

Menumbuhkembangkan pemahaman dan pengamalan ibadah ke tengahtengah masyarakat adalah melalui perekrutan da'i yang di tempatkan di beberapa Kampung di setiap Kecamatan dalam wilayah Kabupaten Aceh Tamiang. Penempatan da'i adalah untuk memberikan pengetahuan tentang keislaman dan peningkatan kualitas ibadah masyarakat.

\section{Syi'ar Islam}

Syìar Islam yang dilaksanakan hanya terpaku pada Peringatan-peringatan Hari Besar Islam. Meskipun demikian Dinas Syari'at Islam tetap dipercayakan sebagai penyelenggaranya kegiatan oleh Pemda Kabupaten Aceh Tamiang. menegenai hal ini, Dinas syariat Islam mengambil strategi dalam berlangsungnya kegiatan tersebut dilaksanakan oleh beberapa orang yang saling berinteraksi satu dengan yang lainnya. Agar tujuan yang ingin dicapai dapat terlaksana dengan efektif.

Dalam Al-Qur'an memiliki pola menanggulangi yang dianggap sesuatu itu adalah kemungkaran, maka solusinyapun dilakukan secara berjama'ah (kelompok). ${ }^{16}$

\footnotetext{
${ }^{16}$ Lihat: QS. Ali Imran/3:104
}

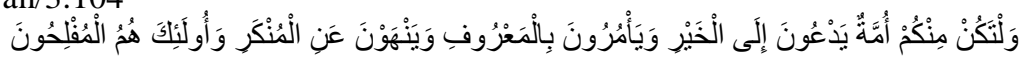

Artinya : "Dan hendaklah ada di antara kamu segolongan umat yang menyeru kepada kebajikan, menyuruh kepada yang ma'ruf dan mencegah dari yang munkar; merekalah orang-orang yang beruntung." 
Politica, Vol. 7, No. 2, Juli-Desember 2020

Maka dengan demikian, Syiar Islam yang harus dilakukan adalah kewajibann yang didahului oleh dua kalimah Syahadat, yang disebutkan adalah rukun-rukun Islam, dan disebukan secara khusus adalah Ibadah. ${ }^{17}$

\section{Penerapan Syariat Islam Tentang Khamar, Maisir dan Khalwat}

Pada awal perjalanan penerapan syari'at Islam di Kabupaten Aceh Tamiang memiliki gairah dan sambutan hangat dari masyarakat. pemerintah Aceh Tamiang menjalakan, mengantisipasi dan memberi sangsi bagi pelanggar.

Sosialisasi qanun syariat Islam ini dilakukan oleh Pol. WH pada kegiatankegiatan khusus yang dilaksanakan oleh Dinas Syari'at Islam baik secara langsung maupun tidak langsung dengan terjun kemasyarakat dan juga melalui kegiatan pelatihan atau pembekalan terhadap aparatur kampung dalam wilayah Aceh Tamiang dan yang disampaikan oleh Pol. WH terutama sekali pada penyampaian masalah qanun tentang khamar, maisir, dan khalwat. Kegiatan sosialisasi ini sering dilakukan dalam bentuk ceramah atau penyampaian secara tatap muka, terkadang terjadi diskusi juga dengan masyarakat tentang pelaksanaan dan penegakan qanun ini, maka bagi masyarakat yang sudah mendapatkan informasi, masyarakat dapat mengatasinya dengan menggunakan hukum adat atau reusam kampung yang telah disepakati untuk menjadi acuan dalam penyelesaian pelanggaran Syari'at Islam di Kampung apabila terjadi pelanggaran.

Signifikansi penyampaian terhadap penerapan Syari'at Islam yang hanya sebatas pada penenerapan Qanun Nomor 11 Tahun 2002, Qanun Nomor 12, 13, dan 14 Tahun 2003 secara keseluruhan dapat dikatakan belum mencapai hasil yang maksimal karena masih banyak kekurangan dan kelemahannya.

Maka proses eksekusi terhadap pelaku pelanggaran dapat terlaksana dengan baik, berhasil diberikan hukuman cambuk. Hal ini dapat terlaksana, karena pelanggar adalah masyarakat biasa. Namun kemudian mendapat kegagalan yang paling fatal adalah manakala salah seorang oknum DPRD yang kedapatan Mesum gagal dieksekusi, karena melakukan banding dan kasasi sampai ke Mahkamah Agung RI yang mengakibatkan masyarakat mulai enggan untuk mematuhi aturan Syari'at Islam. Kejadian ini membuat tugas Pol. WH menjadi berat bahkan cercaan, makian dan hinaan dilontarkan oleh masyarakat kepada petugas Pol. WH pada saat melakukan patroli atau razia di lapangan. Hal ini menjadi kenangan di masa lalu, kini Pol. WH sudah bergabung dengan Satpol PP, yang tugas dan wewenangnya berbeda, terutama dalam mengatasi persoalan Khamar, Mesir, dan Khalwat.

17 Yusuf Qardhawai, Malamih al Mujtama`Al Muslim Alldzi Nusyiduhu, Terjemahan: Abdussalam Syukur, Masyarakat berbasis Syariat Islam: Aqidah, Ibadah, Akhlak, (Surakarta: Era Intermedia, 2003), cet.I, hlm.77 
Politica, Vol. 7, No. 2, Juli-Desember 2020

\section{Kedudukan Dan Fungsi Polisi Wilayatul Hisbah}

Ketika Pol WH berada di bawah Dinas Syari'at Islam, Pol. WH melakukan pengawasan terhadap pelaksanaa, pelanggaran dan penegakan qanun-qanun Syari'at Islam dapat dikatakan berjalan dengan baik, artinya dapat terprogram, terstruktur dan teroganisir melalui pintu Dinas Syari'at Islam, akan tetapi dikarenakan Pol. WH sudah dialihkan ke Satuan Polisi Pamong Praja (Satpol PP), maka kegiatan pengawasan terhadap pelanggaran Syari'at Islam sudah tidak lagi di Dinas Syari'at Islam, namun apabila ada laporan yang patut diduga dan atau terjadinya pelanggaran secara nyata (tertangkap tangan), maka Dinas Syari'at Islam dapat mengajak atau bekerjasama dengan Pol. WH dalam penanggulangan pelanggaran tersebut guna diproses dan diselesaikan sebagaimana dengan ketentuan yang berlaku.

Tugas, fungsi dan wewenang yang dimiliki oleh Dinas Syari'at Islam telah memberikan sumbangsih kepada masyarakat untuk turut serta berpartisipasi aktif dalam melaksanakan Syari'at Islam, mulai dari program pelatihan, pembinaan dan pemberdayaan sampai kepada fasilitator terhadap eksekusi pelaku pelanggaran Syari'at Islam. Ini akan terus dilakukan dengan mengevaluasi atas kekurangan dan kelemahan yang terjadi guna meningkatkan kinerja dan kepercayaan yang diberikan oleh masyarakat sehingga perjalanan penerapan Syari'at Islam di Aceh Tamiang dapat berjalan ebagaimana yang diharapkan.

Berbagai strategi yang digunakan Dinas Syariat Islam dalam implementasi Syari'at Islam di Kabupaten Aceh Tamiang sebagaimana telah disebutkan di atas belum menunjkkan sesuatu hal yang spesifik sebagaimana dengan semangat pemberlakuan Syari'at Islam itu sendiri. Karena semangat pemberlakuan Syari'at Islam itu adalah membangun kesadaran masyarakat semaksimal mungkin agar turut berpartisipasi penuh dalam setiap waktu dan tempat agar Syari'at Islam membumi di kabupaten Aceh Tamiang.

\section{Efiktifitas Implementasi Syari'at Islam}

Sudah menjadi opini publik bahwa pelaksanaan kegiatan yang dilaksanakan oleh seseorang ataupun lembaga, konon lagi lembaga pemerintah maka berbagai tanggapan dan sorotan dari elemen masyarakat memungkinkan akan bermunculan. Mengingat masyarakat merupakan salah satu elemen yang dapat memberikan masukan dan pengawasan atas kinerja yang dilakukan oleh lembaga pemerintah, baik yang bersifat konstruktif ataupun tidak, bukankah pemerintah itu pelayan masyarakat.

Implementasi Syari'at Islam yang dilakanakan oleh Dinas Syari'at Islam belum mencapai titik yang maksimal bahkan terkesan masih jalan di tempat. Megingat, melihat dan merasakan tentang suasana di perkampungan dan di perkotaan dalam wilayah Kabupaten Aceh Tamiang itu masih banyak warga yang 
melanggar Syari'at Islam. Sebut saja, anak remaja perempuan yang tidak berbusana Islami, maraknya perjudian baik dengan terang-terangan atau sembunyi-sembunyi dan hiburan organ tunggal di malam hari yang masih membahana alias masih diperbolehkan, tentunya menjadi catatan bahwa kinerja Dinas Syari'at Islam Aceh Tamiang terkesan lemah bahkan dapat dikatakan impoten. Padahal masyarakat sangat banyak mengharapkan dengan hadirnya Dinas Syari'at Islam dapat membawa perubahan yang lebih baik atas pengamalan masyarakat terhadap ajaran Islam. Namun sangat disayangkan, Dinas Syari'at Islam hanya sebagai pelengkap penderita di jajaran Pemerintah Daerah Kabupaten Aceh Tamiang tidak punya taring dan manfaat kepada masyarakat.

Berbagai pelanggaran yang terjadi atas Syari'at Islam di Aceh Tamiang secara umum belum ada yang tereksekusi oleh penegak qanunnya yang dimotori oleh Dinas Syari'at Islam. Jangankan untuk di eksekusi, dilakukan pencegahannya saja sudah tidak ada lagi. Bahkan terkesan terjadi pembiaran atas pelanggaran Syari'at Islam di Aceh Tamiang. Lihat dan dengar saja jika ada pesta pernikahan, maka hiburan Key Board (Organ Tunggal) dengan menampilkan biduanitanya sangat seronok dalam berpakaian dan hiburannyapun sampai larut malam yang dihiasi oleh minuman keras atau khamar. Belum lagi perjudian terselubung, yang notabenenya sudah tidak menjadi rahasia lagi di tengah-tengah masyarakat namun masih saja dibiarkan keberadaannnya (red : TOGEL). Bahkan ada yang terangterangan seperti judi batu dam (domino) yang hampir di setiap Kampung dalam wilayah Aceh Tamiang ada perjudian tersebut.

Dengan demikian keberadaan Dinas Syar'at Islam di Aceh Tamiang ini dapat di ibaratkan dengan "hidup segan matipun tak mau" dikatakan ada tapi tidak punya kegiatan, walaupun ada tapi sama sekali belum menyentuh ke masyarakat dan dikatakan tidak ada tapi kantor dan personilnya ada.

Dari segala segi yang telah diberlakukan oleh Pemerintah Aceh terhadap pemberlakuan Syari'at Islam secara komplet dengan aturan dan sanksi yang termuat di dalam Qanun Syari'at Islam laksana hanya sebatas lips servis di Aceh Tamiang ini. Di Caffe-caffe yang ada di Aceh Tamiang ini pensekatan-sekatannya sangat terindikasi dijadikan khalwat bagi pemuda-pemudi walau dengan dalih makan minum di sana. Akan tetapi realitasnya dijadikan sarana untuk dapat bercumbu rayu dan bermesraan serta yang menjadi ironi bahwa tempat dan perbuatan itu diketahui oleh personil Dinas Syari'at Islam atau Polisi Wilayatul Hisbah, namun tindakan pencegahannya sama sekali tidak dilakukan. Jika benarbenar ada tentu akan ramai dibicarakan dan terpublikasi di koran-koran atau sampai pada pencambukan.

Peranan yang diberikan kepada Dinas Syari'at Islam sebagai salah satu lembaga pemerintah yang memegang amanah dalam mengimplementasikan Syari'at Islam belum efektif yang signifikan di tengah-tengah masyarakat. 
Peranan yang terlihat hanya sebatas dalam persoalan seremonial-serimonial saja. Seperti pelaksanaaan Peringatan Hari-hari Besar Islam yang dilaksanakan oleh Pemerintah Daerah, maka yang menjadi panitianya adalah dari unsur Dinas Syari'at Islam. Padahal tugas, fungsi dan wewenang Dinas Syari'at Islam jauh lebih besar dari sekedar hanya sebagai panitia-panitia dalam PHBI tersebut. Terjun langsung ke masyarakat dengan melakukan sosialisasi untuk memberikan pemahaman tentang peraturan pemberlakuan Syari'at Islam juga belum menembus kepada masyarakat terpencil. Padahal ini merupakan amanah prioritas yang musti dilaksanakan, namun hanya berdiam diri saja, sementara masyarakat buta akan informasi pelaksanaan Syari'at Islam.

Lebih jauh lagi dari hal di atas, Dinas Syari'at Islam Aceh Tamiang hanya menunggu bola dari masyarakat tanpa menjemput bola. Artinya apabila ada laporan masyarakat menyangkut pelanggaran Syari'at Islam baru menunjukkan jati dirinya dan penyelesaiannyapun hanya sebatas pembinaan dengan menanda tangani surat perjanjian untuk tidak mengulangi lagi perbuatannya. Di lain hal, jika masyarakat tidak melaporkannya, maka tidak dengan pemahaman terhadap pemberlakuan Syari'at Islam ke masyarakat. akibatnya, masyarakat mulai bosan dan tidak lagi melaporkan kepada Dinas Syari'at Islam, sehingga masyarakat mengambil jalan sendiri-sendiri untuk menyelesaikannya.

Ironi dan patut disayangkan, sebuah lembaga yang telah diberikan amanat begitu besar oleh Undang-undang tapi minim sekali mengimplementasikannya ke masyarakat. Sekiranya pegawai Dinas Syari'at Islam Aceh Tamiang sadar akan tanggung jawab dan pentingnya sosialisasi tentang Syari'at Islam ke tengahtengah masyarakat, maka tentunya akan mengajak atau mengundang lembaga lain untuk diajak bekerjasama dalam mengatasi persmasalahan implementasi Syari'at Islam sehingga dapat memenuhi segala sesuatu yang dibutuhkan oleh masyarakat.

Dari penjelasan tersebut di atas, bahwa Dinas Syari'at Islam dalam implementasi Syari'at Islam di Aceh Tamiang, dapat diberikan nilai berdasarkan fakta dan data di lapangan yang dapat disebutkan, seperti :

1. Minimnya sosialisasi Syari'at Islam ke tengah-tengah masyarakat, data ini sebenarnya dapat dibuktikan dari program kegiatan tahunan yang dimiliki oleh Dinas Syari'at islam.

2. Banyaknya pelanggaran Syari'at Islam yang tidak mampu di eksekusi menurut hukum yang telah berlaku dan ditetapkan.

3. Kurangnya kejasama dengan lembaga-lembaga atau organisasi keagamaan dan kemasyarakatan yang ada di Aceh Tamiang dalam mensikapi pemberlakuan Syari'at Islam. Hal ini karena hampir tidak pernah ada publikasi pemberitaan ke media masa menyangkut informasi kerja sama dengan lembaga atau organisasi keagamaan dan kemasyarakatan. 
Politica, Vol. 7, No. 2, Juli-Desember 2020

\section{HAMBATAN YANG DIHADAPI DAN UPAYA YANG DITEMPUN}

Strategi yang digunakan agar implementasi syariat Islam di kabupaten Aceh Tamiang agar menjadi efektif dan efesien, maka pemerintah Kabupaten Aceh Tamiang mendukung program Gubernur Aceh penegakan dan pelaksanaan Syariat Islam ini mulai dari perbatasan Aceh, penempatan da'i-da'i diperbatasan ini merupakan program prioritas Dinas Syariat Islam Kabupaten Aceh Tamiang. Maka, hal ini Pemerintah Kab. Aceh Tamiang melalui Dinas Syaiat Islam menggangkat 50 orang da'i kecamatan yang ditugaskan di kacamatan, yang terdiri dari 213 desa, 33 desa sudah di isi oleh da'i perbatasan yang di anggkat oleh Dinas Syari'at Islam Provinsi, sisanya 180 desa ini kami bagi 50 orang, satu orang da'i ada yang 3 desa dan 4 desa. Da'i yang ada belum memadai melihat daerah yang berbatasan dengan Sumatera Utara ini.

Penegakan Syariat Islam ini dilaksanakan dengan melibatkan Polisi Wilyatul Hisbah (WH) untuk melakukan sosialisasi. WH di sini dibawah kepala Satuan Polisi Pamong Praja unruk dapat mengatur strategi kekuatan dibawah Satuan Polisi Pamong Praja (Satpol PP). Hal ini sesuai yang telah diamanatkan dalam UUPA bahwa WH bernaung di bawah Satpol PP, bukan di bawah dinas syarait Islam. Namun demikian, Dinas Syariat Islam mengusulkan kepada pemerintah Aceh agar Pol WH itu berada dalam naungan DSI, agar lebih mudah mengkoordinirkan sosialisasi qanun syariat Islam kepada masyarakat, sehingga mendapat hasil lebih baik.

Pelaksanaan dan penerapan syari'at Islam di kabupeten Aceh Tamiang merupakan tanggung jawab Dinas Syari'at Islam Provinsi dan Kabupeten/Kota yang diamanatkan oleh UUPA. Maka melakukan sosialisasi Syari'at di Kabupeten Aceh Tamiang tentu lebih menekankan pada pemahaman tentang Dinun Islam, karena kalau orang sudah memahami Islam itu selamat, baik dunia maupun akhirat, tidak perlu penegakan syariat dengan kekerasan, namun perlu diberikan pemahaman, kewajiban shalat, tutup Aurat, antisipasi perbuatan yang dilasang seperti Khamar, maisir dan khalwat. Akan tetapi apabila masyarakat yang melanggar, maka DSI dapat mengambil tindakan, pertama dengan teguran, mengirim surat, dan yang terakhir baru dengan penegakan hukum sesuai dengan aturan yang berlaku.

Secara struktural organisasi DSI Kab. Aceh tamiang memiliki empat bidang yang menangani tugas fungsi yang berbeda-beda namun merupakan satu mata rantai yang tidak dapat dipisahkan, yaitu:

1. Bidang Dakwah dan Peribadatan. Melaksanakan kegiatan PHBI

2. Bidang Bina Sumber Daya Manusia. Perekrutan dan controling da'i kecamatan

3. Bidang Penelitian dan Pengembangan

4. Bidang Pengawasan 
Politica, Vol. 7, No. 2, Juli-Desember 2020

Melaksanakan kegiatan ini DSI Kab. Aceh Tamiang mengacu pada program yang telah dianggarkan dan memiliki program-program prioritas yang tidak terlepas dari visi dan misi,l yaitu dengan memberikan dan memasukan ideide yang ditawarkan kepada :

1. Penyadaran

2. Pembinaan

3. Pelatihan

\section{Hambatan yang dihadapi Dinas Syari'at Islam Dalam Implementasi Syari'at Islam di Aceh Tamiang}

Hambatan merupakan suatu menghalagi terlaksananya implementasi syariat Islam di Kabupaten Aceh Tamiang. Hal ini menggangu proses yang sedang dilaksanakan, baik dalam bentuk psikologi, sosiokultural maupun secara mekanisme. Bukan hanya dinas syariat Islam saja yang mengalami hambatan seperti ini, melainkan dinas-dinas lain yang terkait dalam lingkungan pemerintah Kab. Aceh Tamiang. Demikian juga lembaga-lembaga non pemerintah, dalam melaksanakan kegiatan yang telah diprogramkan akan mengalami atau menemukan hambatan dan biasanya pula hambatan itu muncul ada yang dari dalam dan ada pula yang muncul dari luar. Maka persoalan implementasi Syari'at Islam, Dinas Syari'at Islam Aceh Tamiang menemukan hambatan-hambatan tersebut, di antaranya :

\section{a. Hambatan Internal}

Adapun yang menjadi hambatan dari dalam adalah :

1) Kurangnya porsenil kepegawaiaan yang memiliki keahlian yang baik yang dapat menata program serta melaksanakan program kerja untuk di implementasikan kepada masyarakat kurang mampu untuk menterjamahkan atau menganalisa kondisi yang ada.

2) Latar belakang kepegawaian berbeda-beda dan jentang pun berbeda, sehingga sering terjadi berbeda pebdapat dalam menyusun progran, dan pelaksanaan program, sampai silang pendapat dalam mengimplementasinya ke tengah-tengah masyarakat.

3) Tidak permanennya posisi jabatan yang dimiliki oleh personil pegawai Dinas Syari'at Islam Aceh Tamiang dan selalu silih berganti personilnya dalam waktu yang relatif singkat. Belum program itu selesai dan belum sempai telaksana program tersebut. Sudah berganti pejabat. Maka dilaksanakan oleh orang ynag berbeda yang belum memahami program yang telah disusun.

4) Pengawasan yang lemah. Dinas Syarian Islam tidak dapat menugaskan langsung kepada Pol. WH, karena Pol WH sudah bernaung dibawah 
Politica, Vol. 7, No. 2, Juli-Desember 2020

pengawasan Pol. PP, sehingga dalam Implementasi Syari'at Islam itu harus menempuh berbagai prosedur dan protokoleh. Akhirnya lambat terantisipasinya.

5) Minimnya saarana dan prasarana yang diberikan, walaupun programnya sudah disampaikan dan diajukan kepada pemerintah

\section{b. Hambatan Eksternal}

Di samping hambatan internal dalam implementasikan Syari'at Islam, juga memiliki hambatan yang datangnya dari luar, seperti :

1) Giografis

Kondisional giografis di Aceh Tamiang sangat sulit untuk di jangkau dalam waktu yang singkat karena letak yang sangat jauh dari Ibu Kota Kabupaten dan Kabupaten Aceh Tamiang merupakan pintu masuk keluarnya warga dari berbagai daearah. Kondisi kampungnyapun juga berbeda-beda antara satu kampung dengan kampung lainnya, bahkan kalau musim hujan, kondisi jalan dikampungan banyak yang berlumpur dan kubangan, namun kalau musim panas, maka banyak debunya berterbangan.

Jadi Pantauan dan pengawasan tehadap penerapan Syari'at Islam yang sulit dilakukan secara maksimal, akhirnya tidak dapat dideteksi bahwa kampung tersebut telah melaksanakan Syari'at Islam secara kaffah atau justru sebaliknya, banyak melakukan pelanggaran. Maka dengan demikina, mengingat jarak satu Kecamatan dengan Kecamatan lain, antara Kampung dengan Kampung lain yang benar-benar tidak dapat dilakukan secara cepat. Jangankan untuk hal itu, di tingkat Kampung saja sulit untuk ditempuh antara sesama Dusunnya. Namun kondisional ini bukanlah seluruhnya seperti ini yang terdapat dalam wilayah Aceh Tamiang.

2) Budaya Masyarakat

Sementara ini yang dianggap menjadi hambatan terbesar adalah belum adanya kesamaan persepsi diantara semua komponen masyarakat yang mendiami Aceh Tamiang. Budaya berfikir dan bertindak terhadap implementasi Syari'at Islam terjadi kekeliruan dalam pemahaman masyarakat. Budaya ini sudah lama berkembang di Aceh Tamiang bahkan dapat dikatakan sudah mendarah daging. Kemajemukan warga masyarakat yang berdomisili di Aceh Tamiang dengan berbagai suku telah menunjukan eksistensi yang ditampilkan sebelum pemberlakuan Syari'at Islam di Aceh. Lihat saja dari sisi pesta perkawinan, nikahnya secara Islam tapi pada saat melaksanakan pesta sudah berubah menjadi pesta adat yang dianutnya bahkan jauh dari nilai-nilai Islam. Maka Berbagai macam budaya yang telah 
Politica, Vol. 7, No. 2, Juli-Desember 2020

mengakar di Aceh Tamiang yang tidak sesuai dengan ajaran Islam masih terus berlangsung.

Demikian juga, sisi pergaulan, pergeseran nilai budaya telah menunjukan yang sangat ironis bagi Dinas Syari'at Islam dan sulit untuk mengatasinya. Di mana pergaulan remaja, pemuda bahkan orang tua sekalipun hampir tidak dapat di kontrol lagi. Nuansa ini setiap harinya ditampilkan oleh sebahagian besar warga masyarakat Aceh Tamiang. Pola hidup ini sampai masuk ke dalam rumah-rumah warga yang terkadang tanpa ada pengendalian dari orang tua. Kepedulian masyarakat terhadap pelaksanaan Syari'at Islampun terabaikan.

Masyarakat sudah lebih gandrung dengan kebiasaannya dan sulit langkah untuk diajak ke pengajian-pengajian yang dilaksanakan di kampung tempat tinggalnya, terutama anak remaja dan muda-mudinya memiliki rasa malu dan sangat enggan jika di ajak untuk ikut dalam pengajian dengan berbagai alasan yang dilontarkan untuk menolak ajakan ini. Padahal tanpa dipungut biaya apapun. Akan tetapi jika diajak untuk hal-hal yang sifatnya hura-hura, maka tanpa dimintapun mereka langsung berpartisipasi aktif melaksanakannya.

3) Globalisasi

Lintas keluar masuknya warga dari daerah dan ke Aceh Tamiang merupakan pintu gerbang masuk dari luar ke Aceh. Kemajemukan warga dan budaya adat kebiasaan yang sudah mengakar semakin sinergik dengan arus globalisasi di Aceh Tamiang. Bagai gayung bersambut, masyarakat tanpa memiliki benteng dan filter dalam dirinya langsung menampung secara suka rela dan suka cita dengan datangnya arus globalisasi. Mulai dari sisi cara berpakaian, bergaul dan lain-lain yang menunjukan betapa tragisnya untuk disaksikan.

Sisi negatif lebih tersalurkan dari pada sisi positifnya dari derasnya arus globalisasi ini, mulai dari media (baik media cetak ataupun media elektronik) dengan memberitakan dan mempertontonkan sesuatu yang selalu vulgar dan jarigan informasi yang tiada batas dapat diakses melalui jaringan internet.

\section{Upaya Dinas Syari'at Islam Dalam Mengatasi Hambatan Implementasi Syari'at Islam di Kabupaten Aceh Tamiang.}

Upaya Dinas Syari'at Islam Kabupaten Aceh Tamiang dalam mengatasi hambatan dalam implamentasi syari'at Islam tidak terlepas pernan para Ulama dan da`i serta para guru pengajian dan lembag-lembaga pengajian yang ada. Hal ini menunjukan bahwa sudah menempuh ke seluruh pelosok Kab. Aceh Tamiang. 
hal ini semuanya dibawah tanggung jawab yang diemban oleh Dinas Syari'at Islam. Dengan demikian pemerintah Kab. Aceh Tamiang perlu mendukung sepenuhnya Menghidupkan lembaga-lembaga pendidikan dayah dan madrasah dan tidak lipa menyahuti program Gubernur mengaji ba'da magrib. Pemerintah Kab. Aceh Tamiang sudah mesiapkan sebanyak 48 orang guru gaji dan diangkat lagi sekitar 612 orang yang dibayar insentive oleh Pemerintah Kab. Aceh Tamiang. dengan memperbanyak guru pengajian, maka tidak ada celah bagi masyarakat Aceh Tamiang tidak tirbinanya Akhlak bagi anak-anak melalui mengaji al-Qur'an dan pendidikan aqhlak, jadi semua ini diberi pagar anakananya, orangtuanya, walaipun belum maksimal, sekurang-kurangnya sudah mulai menerapkan syariat Islam dengan tidak memberikan ancaman tetapi memberikan ilmu, agar mereka mengetahui tentang Islam.

Berdasarkan uraian tersebut di atas, maka upaya yang ditempuh dalam menerapkan syari'at Islam di Kab. Aceh Tamiang, di antaranya :

a. Menciptakan kesadaran dan meningkatkan pemahaman bagi masyarakat melalui pembekalan dan pelatihan yang dilaksanakan oleh Dinas Syari'at Islam secara langsung atau melalui para da'i yang telah di tempatkan di berbagai kampung dalam wilayah Kab. Aceh Tamiang, baik da'i yang ditugaskan dari Provinsi Aceh maupun da'i hasil rekrutmen Pemerintah Kab. Aceh Tamiang yang diserahkan kepada Dinas Syari'at Islam. Upaya ini sedang dan akan terus terlaksana dengan menitik beratkan pada :

1. Mengaktifkan kembali pusat-pusat kegiatan keagamaan di kampungkampung, seperti Masjid, Meunasah (Mushalla), Dayah (pesantren), Taman Pendidika Al-Qur'an (TPA), dan Madrasah-madrasah. Ini terus diupayakan difungsikan, maka kejayaan Aceh sebagai pusat studi Islam di Asia Tenggara akan terulangi kembali. Tempat-tempat tersebut, diadakan sosialisasi penerapan syari'at Islam, dengan mengadakan berbagai kegiatan atau halaqah yang melibatkan semua unsur masyarakat. Maka, dengan demikian, ketika penerapan syari'at Islam di Aceh, rakyatnya akan semakin siap. karena, selain sebagai tuntutannya harus terpenuhi, rakyat Aceh telah mempunyai kesepahaman yang sama dalam memandang Syari'at Islam.

2. Mendidik kader-kader muda Islam melaului pelatihan-pelatihan dan pembekalan yang rutin dilaksanakan. Seperti Hafalan Qur'an, Khatib dan Imam. Program ini merupakan program prioritas Dinas Syari'at Islam Aceh Tamiang. Dinas Syari'at Islam telah mencanangkan bagi pemuda yang mampu Tahfiz Qur'an akan diberikan insentif sesuai menurut banyaknya hafalan yang dimiliki dan juga mengangkat pemuda tersebut menjadi Imam Masjid di setiap Kampungnya masing-masing. Pembinaan ini bekerjasama dengan da'i yang ditempatkan dalam wilayah Kab. Aceh Tamiang. 
Politica, Vol. 7, No. 2, Juli-Desember 2020

3. Membangun lembaga-lembagapendidikan Islam. Hal ini, Dinas Syari'at Islam Aceh Tamiang berperan aktif untuk membantu pembangunan fisik lembaga tersebut, baik melalui Anggaran Pendapatan Belanja Daerah (APBD) atau Anggaran Pendapatan Belanja Aceh (APBA).

b. Mewujudkan suasana masyarakat yang gemar dengan aktivitas keagamaan, baik di lingkungan Pemerintah Kab. Aceh Tamiang maupun lingkungan masyarakat luas. Upaya ini dimaksudkan agar setiap program dan pelaksanaan kegiatan keislaman dapat diikutin secara aktif, seperti pengajian rutin bulanan yang dilaksnakan setiap tanggal 17 di jajaran pegawai Pemerintah Daerah Kabupaten Aceh Tamiang, Peringatan Hari-hari Besar Islam yang telah teragendakan pertahunnya, dan Musabaqah Tilawatil Qur'an (MTQ) di setiap tingkatannya serta seluruh paket kegiatan keagamaan yang diamanahkan Pemerintah Daerah kepada Dinas Syari'at Islam. Maka hal ini sangat mendukung penerapan syari'at Islam di $\mathrm{Kb}$. Aceh Tamiang.

c. Selalu berkoordinasi dan bekerjasama dengan lembaga lain dalam pelaksanaan dan penerapan Syari'at Islam. Baik lembaga Pemerintah maupun lembaga lain yang berkopmpeten. Dinas Syari'at Islam Aceh Tamiang tidak mungkin mampu menjwab semua agenda penerapan dan atau pemberlakuan Syari'at Islam tanpa didukung oleh lembaga-lembaga terkait. Sebab itu kerja sama selalu diupayakan, seperti terindikasi adanya pemahaman atau pengamalan agama yang menyimpang (ajaran sesat), penanggulan beredarnya Minuman Keras, maraknya Perjudian dan menjamurnya Khalwat (mesum). Penanggulangan ini berkoordinasi dan kerja sama yang sering dilakukan oleh Dinas Syari'at Islam adalah dengan instansi/lembaga Satuan Polisi Pamong Praja dan Polisi Wilayatul Hisbah (Satpol PP dan Pol. WH). Mengingat di lapangan yang memiliki wewenang adalah lembaga tersebut. Sementara dinas Syari'at Islam hanya sebagai mediator dan fasilitator pelakanaannya, eksikutornya adalah lembaga tersebut. Pada persoalan lain juga sering berkoordinasi dengan Majelis Permusyawaratan Ulama (MPU) terutama dalam menanggulangi penyebaran aliran atau paham keagamaan yang menyimpang dari ajaran Islam.

Penerapan syariat Islam di Kab. Aceh Tamiang masih terlampau muda yang belum tersebar ke seluruh pelosok, lebih-lebih masyarakat pinggiran. Maka pembentukan program dan pelaksanaan belum sepenuhnya tersebar luas. Karena itu metode yang dihadapi dalam sosialisasi Syariat Islam adalah dengan menyentuh hati yang lebih mendalam. Inilah strategi Dinas Syariat Islam dengan merubah strategi mulai menyusun program, pelaksanaan program sampai evaluasi program. Strategi yang digunakan adalah dengan mengajak seluruh elemen masyarakat, mulai sosialisasi sampai antisipasi. DSI dan WH melakukan hal ini secara bersamaan agar penerapan ini berhasil dengan baik. Untuk lebih berhasil 
lagi Kab. Aceh Tamian memposisikan da'i-da'i, baik diperbatasn maupun daerahdaerah tertinggal dengan pemahaman keagamaan. Kedatangan para da'i sangat membantu penerapan syariat islam di Aceh Tamiang.

Demikian juga metode yang dikembangkan oleh DSI Kab. Aceh Tamiang dan WH sesuai dengan bentuk langkah-langkahnya, yaitu DSI Kab. Aceh Tamiang melakukan sosialisasi bukan hanya lisan, bahkan dengan tulisan atau media-media public yang dapat dibaca dan dipahami oleh masyarakat. Kekurangan metode ini, bahwa media yang berkembang dalam masyarakat tidak semua masyarakat mau membaca, hanya segelintir masyarakat yang mau membaca.

Metode ini belum sesuai dengan kondisi masyarakat Kab. Aceh Tamiang. Masyarakat lebih tersentuh dengan menganut tradisi lisan, berbicara dengan cara hati ke hati, maka masyarakat semakin merasuk dalam jiwanya. Tidak menafikan metode sosialisasi, ceramah, anjuran pablik, namun lebih berhasil bila dapat di antar langsung dengan anjuran yang lebih harmonis dengan menyentuh jiwa.

Strategi yang digunakan oleh DSI Kab. Aceh Tamiang sudah sesuai dengan keinginan masyarakat, akan tetapi kadang kala masyarakat itu sendiri yang mengabaikan anjuran dan sosialisasi Pemda Kab. Aceh Tamiang melalui DSI dan WH.

Berdasarkan kesadaran yang dijalankan oleh DSI dan WH, masih banyak masyarakat yang belum mematuhi dan menataati syariat Islam, keberhasilan DSI sudah mulai dampak pada segelintir masyarakat bahwa mereka sudah mengetahui dan mentaati syariat Islam dengan baik. Keberhasilan DSI dan WH membuat Pemda Kab. Aceh Tamiang lebih bangga dan bertambah semangat dalam implementasi Syariat Islam di Kab. Aceh Tamiang.

\section{E. KESIMPULAN}

Berdasarkan uraian dan pembahasan tersbut di atas, maka dapat diambil kesimpulan bahwa:

1. Dinas syariat Islam melakukan implementasi syariat Islam di Perbatasan Kab. Aceh Tamiang mengambi strategi adalah membeuta progran, mensosialisasikan, menerapkan dan antisipasi, program Dinas Syariat Islam adalah membina dan menerapkan Syariat Islam Kab. Aceh Tamiang dengan baik dan tersentuh hati masyarakat agar masyarakat mau mematuhi dan mentaati Syariat Islam.

2. Hambatan yang di hadapi oleh Dinas Syariat Islam Ka. Aceh Tamiang adalah pemahaman masyarakat yang dangkal terhadap syariat Islam, kebudayaan yang tidak islami yang melekat dalam kehidupan masyarakat, personil yang kurang bagii dinas Syariat Islam serta fasilitas yang tidak seimbang dalam melakukan implementasi syariat Islam. 
Politica, Vol. 7, No. 2, Juli-Desember 2020

3. Uapaya Dinas Syariat Islam Aceh Tamiang sudah melakukan dan mengimplementasikan syariat Islam adalah dengan mengirimkan tim sosialisasi dan antisipasi yaitu tim pembinaan masyarakat dengan memposisikan para da'i di daerah-daerah perbatasan dan daerah-daerah terpencil, dengan mengisi lembaga-lembaga pendidikan dan penyuluhan agama dalam masyarakat Kab. Aceh Taming.

\section{DAFTAR PUSTAKA}

Ahmad Kamil dan M Fauzan, Kaedah-Kaedah Hukum Yurisprudensi, (Jakarta:

Kencana, 2008), Ed.I, Cet. III, hlm.19

Hasanuddin Yusuf Adan, Repleksi Implementasi Syari'at Islam di Aceh, (Banda Aceh : Adnin Foundation Publisher \& Pena, 2009).

Ni matul Huda, Otonomi Daerah: Filosofi, Sejarah perkembangan dan Problematika, (Yokyakarta: Pustaka Pelajar, 2009), Cer II, hlm. 3

Puspitawati, Herien. 2009. Teori Struktural Fungsional dan Aplikasinya Dalam

Kehidupan Keluarga, (Bogor : Departemen Ilmu Keluarga dan Konsumen, 2009)

Puspitawati, Herien. 2009. Teori Struktural Fungsional dan Aplikasinya Dalam

Kehidupan Keluarga, (Bogor : Departemen Ilmu Keluarga dan Konsumen, 2009), hlm. 2.

R. Megawangi,R, Membiarkan Berbeda : Sudut Pandang Baru Tentang Relasi Gender, (Jakarta: Pustaka Mizan, 2001)

Robert H. Lauer, Perspektif Tentang Perubahan Sosial, alih bahasa Alimandan. (Jakarta : Bina Aksara, 1989).

Sunarto, Kamanto, Pengantar Sosiologi, (Jakarta : Lembaga Penerbit FE UI, 2004).

Wiryanto, Pengantar Ilmu Komunikasi, (Jakarta: Gramedia Widiasavina, 2004).

Yusuf Qardhawai, Malamih al Mujtama`Al Muslim Alldzi Nusyiduhu, Terjemahan: Abdussalam Syukur, Masyarakat berbasis Syariat Islam: Aqidah, Ibadah, Akhlak, (Surakarta: Era Intermedia, 2003).

UU No. 24 tahun 1956 Pembentukan Daerah Otonom Propinsi Atjeh.

UU No. 44 tahun 1999 tentang Pemberlakukan Hak Insimewa Aceh.

UU Nomor 18 Tahun 2001 tentang Otonomi khusus Bagi Provinsi Daerah Istimewa Aceh sebagai Provinsi NanggroeAceh Darussalam, 